\title{
Polynuclear and one-dimensional cyanide-bridged heterobimetallic complexes: synthesis, crystal structures and magnetic properties
}

\author{
JINGWEN SHI ${ }^{\mathrm{a}}$, WENLONG LAN ${ }^{\mathrm{a}}$, YIN ZHOU ${ }^{\mathrm{a}}$, CHONGCHONG XUE ${ }^{\mathrm{a}}$, QINGYUN LIU ${ }^{\mathrm{b}}$ and \\ DAOPENG ZHANG ${ }^{\mathrm{a}, *}$ \\ ${ }^{a}$ College of Chemistry and Chemical Engineering, Shandong University of Technology, Zibo 255049, People's \\ Republic of China \\ ${ }^{\mathrm{b}}$ College of Chemical and Environmental Engineering, Shandong University of Science and Technology, \\ Qingdao 266510, People's Republic of China \\ E-mail: dpzhang73@126.com
}

MS received 30 September 2017; revised 26 December 2017; accepted 27 December 2017;

published online 7 February 2018

\begin{abstract}
Three new heterobimetallic cyanide-bridged complexes, $\left\{\left[\mathrm{Ni}\left(\mathrm{L}^{1}\right)\right]\left[\mathrm{Ag}(\mathrm{CN})_{2}\right]\right\}\left[\mathrm{Ag}(\mathrm{CN})_{2}\right]$. $2 \mathrm{H}_{2} \mathrm{O}(2),\left\{\left[\mathrm{Mn}\left(\mathrm{L}^{2}\right)\right]\left[\mathrm{Ag}(\mathrm{CN})_{2}\right]\right\} \cdot 1.5 \mathrm{H}_{2} \mathrm{O}(3)$ and $\left\{\left[\mathrm{Mn}\left(\mathrm{L}^{3}\right)\left(\mathrm{H}_{2} \mathrm{O}\right)\right]_{2}\left[\mathrm{Ag}(\mathrm{CN})_{2}\right]\right\} \mathrm{ClO}_{4} \cdot 2 \mathrm{H}_{2} \mathrm{O}(\mathbf{4})\left(\mathrm{L}^{1}=\right.$ 2,7,12-trimethyl-3,7,11,17-tetraazabicyclo[11.3.1] heptadeca-1(17),13,15-triene; $\mathrm{L}^{2}=\mathrm{N}, \mathrm{N}^{\prime}-1,3$-propylenebis(5-chlorosalicylideneiminate); $\mathrm{L}^{3}=\mathrm{N}, \mathrm{N}^{\prime}-1,2$-propylene-bis(5-bromosalicylideneiminate)), have been assembled using for the first time a new polyaza macrocycle nickel(II) compound $\left[\mathrm{Ni}\left(\mathrm{L}^{1}\right)\right]\left(\mathrm{ClO}_{4}\right)_{2}(\mathbf{1})$, or Schiff-base manganese(III) compounds and $\mathrm{K}\left[\mathrm{Ag}(\mathrm{CN})_{2}\right]$. Single crystal X-ray diffraction analysis reveals that complexes $\mathbf{2}$ and $\mathbf{3}$ can be characterized as one-dimensional cationic and neutral single chain structure, respectively. Complex 3 forms a three-dimensional network via weak inter-chain Ag... Ag interactions. Complex 4 belongs to a cyanide-bridged bimetallic sandwich-like cationic trinuclear structure containing $\mathrm{Mn}_{2} \mathrm{Ag}$ core with free $\mathrm{ClO}_{4}^{-}$as a counter anion, indicating that the Schiff-base ligand has an obvious influence on the structure of the cyanide-bridged complexes formed. Investigation of the magnetic susceptibilities of the cyanide-bridged Ag$\mathrm{Ni}(\mathrm{II}) / \mathrm{Mn}$ (III) complexes showed the weak anti-ferromagnetic interaction between neighboring paramagnetic $\mathrm{Ni}(\mathrm{II})$ or $\mathrm{Mn}(\mathrm{III})$ ions bridged by the long NC-Ag-CN unit. From the best-fit of the magnetic susceptibility data of complexes 2 and $\mathbf{4}$ the magnetic coupling constant was determined to be $J=-0.51$ and $-0.78 \mathrm{~cm}^{-1}$, respectively.
\end{abstract}

Keywords. Cyanide-bridged complex; heterobimetallic complex; crystal structure; magnetic property.

\section{Introduction}

In the recent past decades, many effective strategies have been developed to rationally assemble metal complexes with diversified topological structures and interesting properties with the ultimate goal of obtaining molecular materials with new structures, properties and functions. Due to the significant role of the cyanide group as a remarkable linker in tuning the magnetic coupling between the paramagnetic centers and excellent stabilizing ability on a variety of transition metal centers with or without the periheral ligands, the cyanide-bridged magnetic complexes have been widely studied in the field of molecular magnetism. ${ }^{1-6}$ Usually the rational design of cyanide-bridged magnetic systems is achieved following the practical method of assembling appropriate

\footnotetext{
*For correspondence
}

cyano precursors exhibiting targeted chemical and physical properties (local anisotropy, spin state, etc.) and various paramagnetic metal ions with or without the ancillary organic ligands, which have resulted in many cyanide-bridged complexes with diverse structures and interesting magnetic properties. ${ }^{7-27}$

The peripheral ligands attached to the paramagnetic counterpart assembled segment have an obvious influence on the structure of the resulting complexes. Therefore, for the purpose of tuning the structure of the cyanide-bridged complexes, many mono- or multidentate organic ligands with different structures and steric effects have been used to block the paramagnetic metal ions. Among which, we are interested in quasi-planar macrocyclic and Schiff-base ligands. The polyaza semi-rigid macrocyclic ligands obtained by condensation of 2,6-diacetylpyridine and polyamine have proven to be good ancillary ligands to assemble 
cyanide-bridged complexes. Some $\mathrm{Ni}(\mathrm{II}), \mathrm{Mn}(\mathrm{II})$ or $\mathrm{Fe}$ (II) complexes with different structures and interesting magnetic properties based on the above polyaza macrocyclic ligand have been reported. ${ }^{28-33}$ On the other hand, due to their facile preparation, and more importantly due to the large spin state $(S=2)$ as well as the usual negative magnetic anisotropy of the central $\mathrm{Mn}$ (III) ion, which can sometime result in interesting magnetic phenomenoa, the Schiff-base manganese(III) compounds based on quasi-planar tetradentate $\mathrm{N}_{2} \mathrm{O}_{2}$ or $\mathrm{N}_{2} \mathrm{O}_{4}$ Salen-type ligands (Salen $=\mathrm{N}, \mathrm{N}$ bis(salicilydene)ethane-1,2-diamine have drawn much interest for constructing molecular magnets. ${ }^{4-6}$

$\left[\mathrm{Ag}(\mathrm{CN})_{2}\right]^{-}$with two cyanide groups in a trans position can be used to assemble $1 \mathrm{D}$ to $3 \mathrm{D}$ coordination polymers based on the coordination bond and Ag...Ag interactions. Several silver polymer examples with diverse structures and interesting optical properties have been reported. ${ }^{34-36}$ In this paper, we report the investigation of the reactions of trans-dicyanometallate $\mathrm{K}\left[\mathrm{Ag}(\mathrm{CN})_{2}\right]$ with a new macrocyclic nickel compound $\left[\mathrm{Ni}\left(\mathrm{L}^{1}\right)\right]\left(\mathrm{ClO}_{4}\right)_{2}(\mathbf{1})$, whose structure has also been crystallographically characterized, or Schiff-base manganese(III) compounds, resulting in three cyanidebridged bimetallic complexes with different structure types formulated as $\left\{\left[\mathrm{Ni}\left(\mathrm{L}^{1}\right)\right]\left[\mathrm{Ag}(\mathrm{CN})_{2}\right]\right\}\left[\mathrm{Ag}(\mathrm{CN})_{2}\right]$. $2 \mathrm{H}_{2} \mathrm{O}(2),\left(\mathrm{L}^{1}=2,7,12\right.$-trimethyl-3,7,11,17-tetraazabic yclo[11.3.1]heptadeca-1(17),13,15-triene), $\left\{\left[\mathrm{Mn}\left(\mathrm{L}^{2}\right)\right]\right.$ $\left.\left[\mathrm{Ag}(\mathrm{CN})_{2}\right]\right\} \cdot 1.5 \mathrm{H}_{2} \mathrm{O} \quad(3)$ and $\left\{\left[\mathrm{Mn}\left(\mathrm{L}^{3}\right)\left(\mathrm{H}_{2} \mathrm{O}\right)\right]_{2}\right.$ $\left.\left[\mathrm{Ag}(\mathrm{CN})_{2}\right]\right\} \mathrm{ClO}_{4} \cdot 2 \mathrm{H}_{2} \mathrm{O}(\mathbf{4})\left(\mathrm{L}^{2}=\mathrm{N}, \mathrm{N}^{\prime}-1,3\right.$-propyl ene-bis(5-chlorosalicylideneiminate); $\mathrm{L}^{3}=\mathrm{N}, \mathrm{N}^{\prime}-1,2$ propylene-bis(5-bromosalicylideneiminate)). The synthesis, crystal structures and magnetic properties for the above mentioned four complexes are presented here. The results provide some meaningful information for the designed synthesis of low-dimensional cyanide-bridged bimetallic complexes with the macrocyclic nickel or manganese Schiff-base compound as assembled segments.

\section{Experimental}

Elemental analyses of carbon, hydrogen, and nitrogen were carried out with an Elementary Vario El. The infrared spectra on $\mathrm{KBr}$ pellets were performed on a Magna-IR 750 spectrophotometer in the $4000-400 \mathrm{~cm}^{-1}$ region. Variable temperature magnetic susceptibility and field dependent magnetization measurements were performed on a Quantum Design MPMS SQUID magnetometer. The experimental susceptibilities were corrected for the diamagnetism of the constituent atoms (Pascal's tables).

\subsection{General Procedures and Materials}

All the chemicals and solvents used were reagent grade and used without further purification. All the reactions were carried out in air atmosphere. $\left[\mathrm{NiL}^{1}\right]\left(\mathrm{ClO}_{4}\right)_{2}$ was prepared according to the reported method for its analogue with slight modification. ${ }^{37}$ The two Schiff-base manganese compounds were synthesized by the method described in the literature. ${ }^{38}$

Caution! KCN is hypertoxic and hazardous. Perchlorate salts of metal complexes with organic ligands are potentially explosive. They should be handled in small quantities with care.

\subsection{The synthesis of compound 1}

To an ethanol solution (60 mL) of 2,6-Diacetylpyridine (3.26 g, $0.02 \mathrm{~mol})$ was added Nickel(II) perchlate hexahydrate $(7.3 \mathrm{~g}, 0.02 \mathrm{~mol})$. The mixture solution was heated to about $65^{\circ} \mathrm{C}$ and $\left.2.9 \mathrm{~g} 0.02 \mathrm{~mol}\right)$ of 3,3'-diamino-(N-methyl) dipropylamine was added, and the solution was refluxed for about $6 \mathrm{~h}$, after which the solution was condensed on a rotary evaporator to reduce the volume of the solution to about 15 $\mathrm{mL}$. After filtering the remaining solution to remove the tiny insoluble materials, excess of ether was added to precipitate the target compound. The product was collected by filtration, washed with ether and dried in air. Yield: about $65 \%$. Anal. Calcd. for $\mathrm{C}_{16} \mathrm{H}_{24} \mathrm{Cl}_{2} \mathrm{~N}_{4} \mathrm{NiO}_{8}$ : C, 36.26; $\mathrm{H}, 4.57 ; \mathrm{N}, 10.57 \%$. Found: C, 36.21; H, 4.51; N, 10.68\%.

\subsection{The synthesis of complex 2}

To a solution of $\left[\mathrm{NiL}^{1}\right]\left(\mathrm{ClO}_{4}\right)_{2}(52.9 \mathrm{mg}, 0.10 \mathrm{mmol})$ in methanol $(10 \mathrm{~mL}), \mathrm{K}\left[\mathrm{Ag}(\mathrm{CN})_{2}\right](19.9 \mathrm{mg}, 0.20 \mathrm{mmol})$ dissolved in methanol/water $(4: 1, \mathrm{v}: \mathrm{v})(10 \mathrm{~mL})$ was carefully added. The resulting mixture was filtered at once and the filtrate was kept undisturbed at room temperature in the dark. After two weeks, dark-brown block crystals were collected by filtration with the yield of $42.0 \mathrm{mg}, 63.6 \%$. $\mu_{\text {eff }}=2.83$ B.M. Anal. Calcd. For $\mathrm{C}_{19} \mathrm{H}_{26.5} \mathrm{Ag}_{2} \mathrm{~N}_{7} \mathrm{NiO}_{2}: \mathrm{C}, 34.61 ; \mathrm{H}, 4.05 ; \mathrm{N}$, $14.87 \%$. Found: C, 34.49; H, 3.85; N, 14.68\%. Main IR bands $\left(\mathrm{cm}^{-1}\right): 2125,2160\left(\mathrm{~s}, v_{\mathrm{C} \equiv \mathrm{N}}\right), 1615,1625\left(\mathrm{vs}, v_{\mathrm{C}=\mathrm{N}}\right)$.

\subsection{The synthesis of complexes 3 and 4}

A solution containing $\mathrm{K}\left[\mathrm{Ag}(\mathrm{CN})_{2}\right](19.9 \mathrm{mg}, 0.10 \mathrm{mmol})$ dissolved in $5 \mathrm{~mL}$ of distilled water was laid in the bottom of a tube, upon which a mixed solvent of water and acetonitrile and methanol with a ratio of 1:2:1 was carefully added. Then, $\left[\mathrm{Mn}\left(\mathrm{L}^{2}\right)\left(\mathrm{H}_{2} \mathrm{O}\right)_{2}\right] \mathrm{ClO}_{4}(54 \mathrm{mg}, 0.10 \mathrm{mmol})$ or $\left[\mathrm{Mn}\left(\mathrm{L}^{3}\right)\left(\mathrm{H}_{2} \mathrm{O}\right)_{2}\right] \mathrm{ClO}_{4}(62.9 \mathrm{mg}, 0.10 \mathrm{mmol})$ dissolved in a mixture $(5 \mathrm{~mL})$ of $\mathrm{CH}_{3} \mathrm{OH}$ and $\mathrm{CH}_{3} \mathrm{CN}$ was carefully added to the top of the mixed solvent layer. Single crystals suitable for X-ray diffraction were obtained from the solvent layer after one/two weeks, which were then collected by filtration and dried in air.

Complex 3: Yield $35.1 \mathrm{mg}, 59.4 \% . \mu_{\mathrm{eff}}=5.91$ B.M. Anal. Calcd. for $\mathrm{C}_{19} \mathrm{H}_{17} \mathrm{AgCl}_{2} \mathrm{MnN}_{4} \mathrm{O}_{3.5}: \mathrm{C}, 38.61 ; \mathrm{H}, 2.90 ; \mathrm{N}$, 
Table 1. Crystallographic data for complexes 1-4.

\begin{tabular}{lcccc}
\hline & 1 & 2 & 3 & 4 \\
\hline Chemical & $\mathrm{C}_{16} \mathrm{H}_{24} \mathrm{Cl}_{2}$ & $\mathrm{C}_{19} \mathrm{H}_{26.5} \mathrm{Ag}_{2}$ & $\mathrm{C}_{19} \mathrm{H}_{17} \mathrm{Ag}$ & $\mathrm{C}_{36} \mathrm{H}_{36} \mathrm{AgBr}_{4}$ \\
Formula & $\mathrm{N}_{4} \mathrm{NiO}_{8}$ & $\mathrm{~N}_{7} \mathrm{NiO}_{2}$ & $\mathrm{Cl}_{2} \mathrm{MnN}_{4} \mathrm{O}_{3.5}$ & $\mathrm{ClMn}_{2} \mathrm{~N}_{6} \mathrm{O}_{12}$ \\
$\mathrm{Fw}$ & 530.00 & 659.42 & 591.08 & 1317.55 \\
Crystal system & Orthorhombic & Orthorhombic & Monoclinic & Monoclinic \\
Space group & Pna2(1) & $\mathrm{Fdd} 2$ & $\mathrm{C} 2 / \mathrm{c}$ & $\mathrm{C} 2 / \mathrm{c}$ \\
$a / \AA$ & $12.2052(8)$ & $19.819(3)$ & $17.371(6)$ & $21.745(5)$ \\
$b / \AA$ & $14.0267(9)$ & $50.218(6)$ & $12.723(4)$ & $16.123(5)$ \\
$c / \AA$ & $12.7334(9)$ & $10.5278(13)$ & $20.224(7)$ & $15.260(4)$ \\
$\alpha /$ deg & 90 & 90 & 90 & 90 \\
$\beta /$ deg & 90 & 90 & $103.639(6)$ & $113.580(7)$ \\
$\gamma /$ deg & 90 & 90 & 90 & 90 \\
$V / \AA \AA^{3}$ & $2179.9(3)$ & $10478(2)$ & $4344(3)$ & $4903(2)$ \\
$Z$ & 4 & 16 & 8 & 4 \\
Completeness & $99.9 \%$ & $98.5 \%$ & $99.0 \%$ & $99.7 \%$ \\
$F(000)$ & 1096 & 5240 & 2344 & 2576 \\
$\theta /$ deg & 2.16 to 25.01 & 1.62 to 25.01 & 2.00 to 25.02 & 1.62 to 25.01 \\
$G O F$ & 1.081 & 1.063 & 1.072 & 1.039 \\
$R_{1}[I>2(I)]$ & 0.0361 & 0.0878 & 0.0537 & 0.0698 \\
$w R_{2}$ (all data) & 0.1003 & 0.2659 & 0.1617 & 0.2395 \\
\hline
\end{tabular}

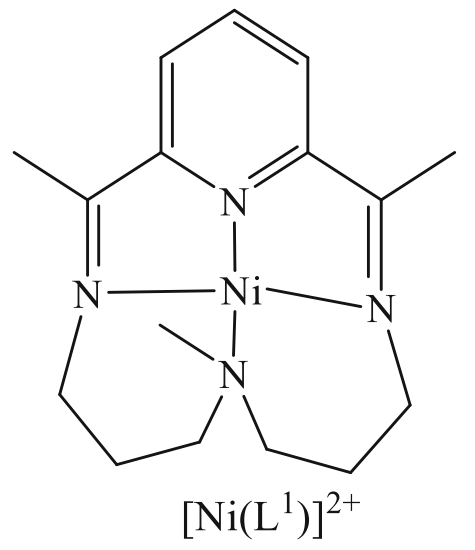

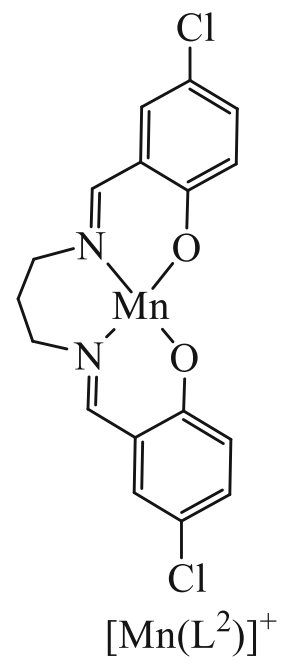

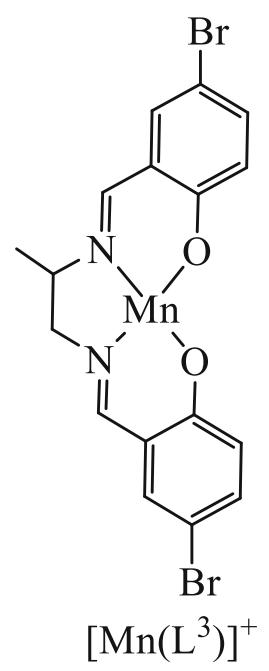

Scheme 1. The starting materials used to prepare the complexes 2-4.

9.48\%. Found: C, 38.71; H, 2.81; N, 9.36\%. Main IR bands $\left(\mathrm{cm}^{-1}\right): 2125\left(\mathrm{~s}, v_{\mathrm{C} \equiv \mathrm{N}}\right), 1620,1625\left(\mathrm{vs}, v_{\mathrm{C}=\mathrm{N}}\right)$.

Complex 4: Yield $40 \mathrm{mg}, 60.7 \%$. $\mu_{\mathrm{eff}}=5.91$ B.M. Anal. Calcd. For $\mathrm{C}_{36} \mathrm{H}_{36} \mathrm{AgBr}_{4} \mathrm{ClMn}_{2} \mathrm{~N}_{6} \mathrm{O}_{12}: \mathrm{C}, 32.81 ; \mathrm{H}, 2.75 ; \mathrm{N}$, $6.38 \%$. Found: C, 32.70; H, 2.65; N, 6.29\%. Main IR bands $\left(\mathrm{cm}^{-1}\right): 2122\left(\mathrm{~s}, v_{\mathrm{C} \equiv \mathrm{N}}\right), 1622,1627\left(\mathrm{vs}, v_{\mathrm{C}=\mathrm{N}}\right), 1100(\mathrm{~s}$,

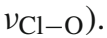

\subsection{X-ray Data Collection and Structure Refinement}

The crystal data were collected on an Oxford Diffraction Gemini E diffractometer with Mo $K \alpha$ radiation $(\lambda=$
$0.71073 \AA$ ) at the room temperature. Final unit cell parameters were derived by global refinements of reflections obtained from integration of all the frame data. CrysAlisPro Agilent Technologies software was used to collect frames of data and for the determination of lattice constants. The structures were solved by the direct method (SHELXS-97) and refined by full-matrix least-squares (SHELXL-97) on $F^{2} .{ }^{39}$ The nonhydrogen atoms were refined anisotropically, while hydrogen atoms were introduced as fixed contributors. All the nonhydrogen atoms, except the disordered ones, were refined with anisotropic displacement coefficients. For the disordered contents, the partially occupied atoms were refined isotropically. Hydrogen atoms were added geometrically and refined using a riding model, except some of the solvent $\mathrm{H}$ atoms. 
For these $\mathrm{H}$ atoms, they were refined isotropically with fixed $\mathrm{U}$ values and the DFIX command was used to rationalize the bond parameter. The crystallographic data for complexes 1-4 are listed in Table 1. CCDC 1575943-1575946 for complexes 1-4 contain the supplementary crystallographic data for this paper. These data can be obtained free of charge from the Cambridge Crystallographic Data Centre via www.ccdc. cam.ac.uk/data_request/cif.

\section{Results and Discussion}

\subsection{Synthesis and general characterization}

As shown in Scheme 1, similar to its analogue $[\mathrm{NiL}]^{37}$ $\left(\mathrm{ClO}_{4}\right)_{2}(\mathrm{~L}=2,12$-trimethyl-3,7,11,17-tetraazabicyclo [11.3.1] heptadeca-1(17),13,15-triene), which has been proved to be an excellent candidate to assemble cyanidebridged magnetic complexes, the new macrocyclic nickel compound $\left[\mathrm{NiL}^{1}\right]\left(\mathrm{ClO}_{4}\right)_{2}$ (1) contains 14-mem bered polyaza macrocycle which adopts a planar conformation. A tetragonal geometry on the central metal ion with different electronic configuration is imposed, leading to the stabilization of the six-coordinated species. Therefore, as expected, the reaction between the trans$\mathrm{K}\left[\mathrm{Ag}(\mathrm{CN})_{2}\right]$ and the newly synthesized nickel compound results in the one-dimensional infinite cyanidebridged Ni-Ag complex. Considering that the trans$\left[\mathrm{Ag}(\mathrm{CN})_{2}\right]^{-}$is a good linear cyanide precursor and more in favor of forming 1D structure, we investigated the reactions of this building block with two Schiff-base manganese(III) compound, which has two replaceable trans positions, and obtained two cyanide-bridged AgMn complexes with different structures, indicating that different Schiff-base ligands have obvious influence on the structure of the target complexes.

All the cyanide-bridged complexes have been characterized by IR spectroscopy. In the IR spectra of complex 2, the two sharp peaks due to the cyanide-stretching vibration were observed in the range of 2120 and 2160 $\mathrm{cm}^{-1}$, respectively, indicating the presence of bridging and non-bridging cyanide ligands in these complexes. For complexes $\mathbf{3}$ and $\mathbf{4}$, the single peak at about 2125 $\mathrm{cm}^{-1}$ can be assigned to the bridging cyanide group. Observation of a strong broad peak centered at ca. 1100 $\mathrm{cm}^{-1}$ for complexes $\mathbf{1}$ and $\mathbf{4}$ suggests the presence of $\mathrm{ClO}_{4}^{-}$anion.

\subsection{Crystal Structure of Complexes 1-4}

Some important structural parameters for complexes 1-4 are collected in Tables 2 and 3. The cationic mononuclear structure of complex $\mathbf{1}$ is shown in Figure 1 . For complex $\mathbf{2}$, asymmetric cationic binuclear unit
Table 2. Selected bond lengths $(\AA)$ and angles $\left(^{\circ}\right)$ for complexes $\mathbf{1}$ and $\mathbf{2}$.

\begin{tabular}{llll}
\hline $\mathbf{1}$ & \multicolumn{3}{c}{$\mathbf{2}$} \\
\hline $\mathrm{Ni}(1)-\mathrm{N}(1)$ & $1.814(4)$ & $\mathrm{Ni}(1)-\mathrm{N}(1)$ & $2.12(3)$ \\
$\mathrm{Ni}(1)-\mathrm{N}(2)$ & $1.922(3)$ & $\mathrm{Ni}(1)-\mathrm{N}(2)$ & $2.14(3)$ \\
$\mathrm{Ni}(1)-\mathrm{N}(3)$ & $1.923(3)$ & $\mathrm{Ni}(1)-\mathrm{N}(4)$ & $1.944(10)$ \\
$\mathrm{Ni}(1)-\mathrm{N}(4)$ & $1.945(4)$ & $\mathrm{Ni}(1)-\mathrm{N}(5)$ & $2.079(14)$ \\
$\mathrm{Cl}(1)-\mathrm{O}(1)$ & $1.392(5)$ & $\mathrm{Ni}(1)-\mathrm{N}(6)$ & $2.085(12)$ \\
$\mathrm{Cl}(1)-\mathrm{O}(2)$ & $1.344(5)$ & $\mathrm{Ni}(1)-\mathrm{N}(7)$ & $2.056(14)$ \\
$\mathrm{Cl}(1)-\mathrm{O}(3)$ & $1.373(6)$ & & \\
$\mathrm{Cl}(1)-\mathrm{O}(4)$ & $1.330(5)$ & $\mathrm{C}(1)-\mathrm{N}(1)-\mathrm{Ni}(1)$ & $168.1(2)$ \\
\hline
\end{tabular}

Table 3. Selected bond lengths $(\AA)$ and angles $\left({ }^{\circ}\right.$ ) for complexes 3 and $\mathbf{4}$.

\begin{tabular}{lcc}
\hline & $\mathbf{3}$ & $\mathbf{4}$ \\
\hline $\mathrm{Mn}(1)-\mathrm{N}(1)$ & $2.242(6)$ & $2.264(9)$ \\
$\mathrm{Mn}(1)-\mathrm{N}(2)$ & $2.260(6)$ & $1.969(9)$ \\
$\mathrm{Mn}(1)-\mathrm{N}(3)$ & $2.026(5)$ & $1.983(9)$ \\
$\mathrm{Mn}(1)-\mathrm{N}(4) / \mathrm{O} 4$ & $2.054(6)$ & $2.317(7)$ \\
$\mathrm{Mn}(1)-\mathrm{O}(1)$ & $1.896(5)$ & $1.861(7)$ \\
$\mathrm{Mn}(1)-\mathrm{O}(2)$ & $1.883(5)$ & $1.889(7)$ \\
$\mathrm{C}(1)-\mathrm{N}(1)-\mathrm{Mn}(1)$ & $168.0(6)$ & $163.6(11)$ \\
\hline
\end{tabular}

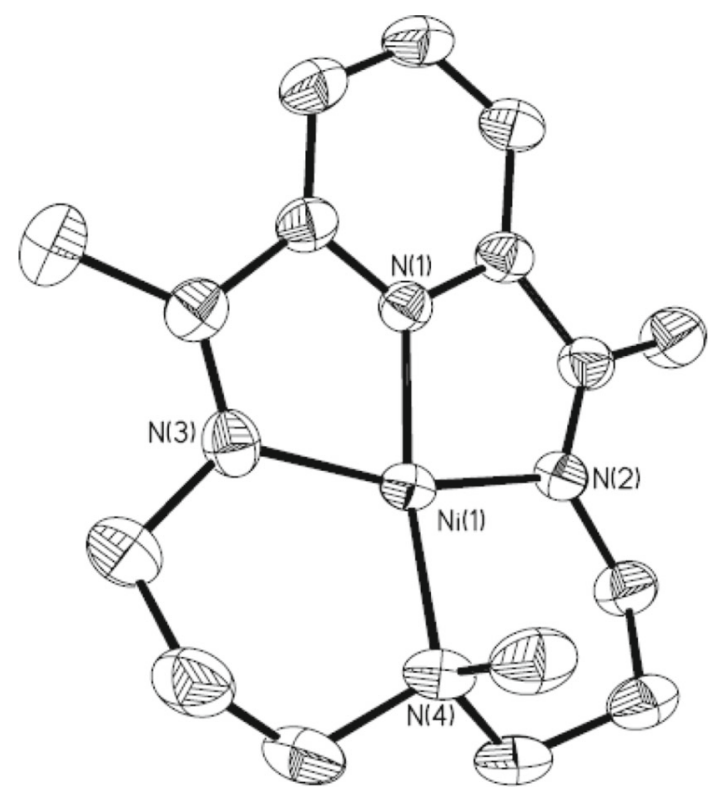

Figure 1. The cationic mononuclear structure of the compound 1. Displacement ellipsoids are drawn at $30 \%$ probability level. The $\mathrm{ClO}_{4}^{-}$anions and all the $\mathrm{H}$ atoms have been omitted for clarity.

and the one-dimensional cationic single chain structure are shown in Figure 2. As can be found, the mononuclear $\left[\mathrm{Ni}\left(\mathrm{L}^{1}\right)\right]^{2+}$ cation contains the four-coordinated nickel ion, for which the four coordination positions are from 

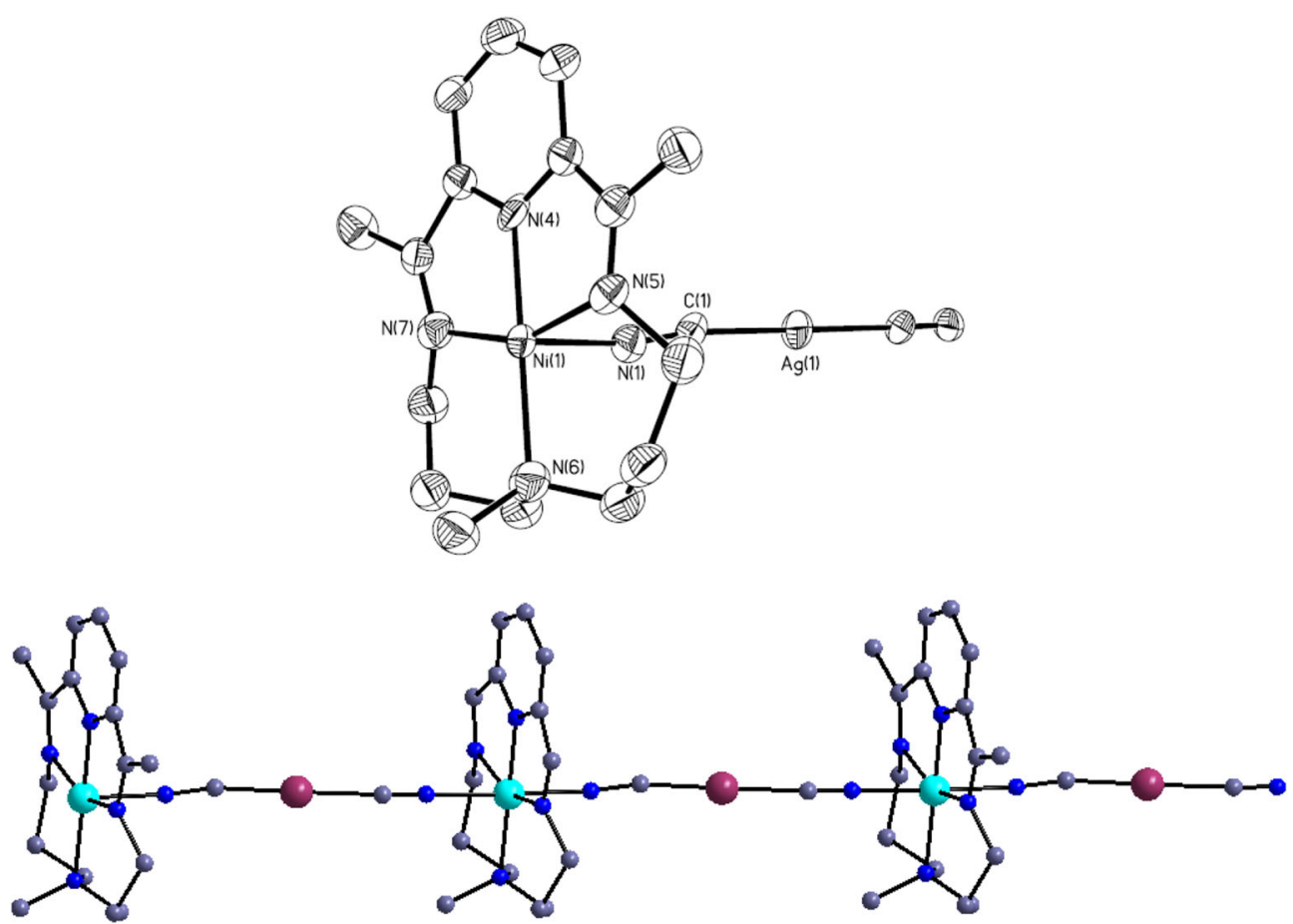

Figure 2. The asymmetric cationic unit and one-dimensional cationic infinite structure of complex 2. Displacement ellipsoids are drawn at the probability level of $30 \%$. All the hydrogen atoms, the solvent molecules and the free $\left[\mathrm{Ag}(\mathrm{CN})_{2}\right]^{-}$have been omitted for clarity.
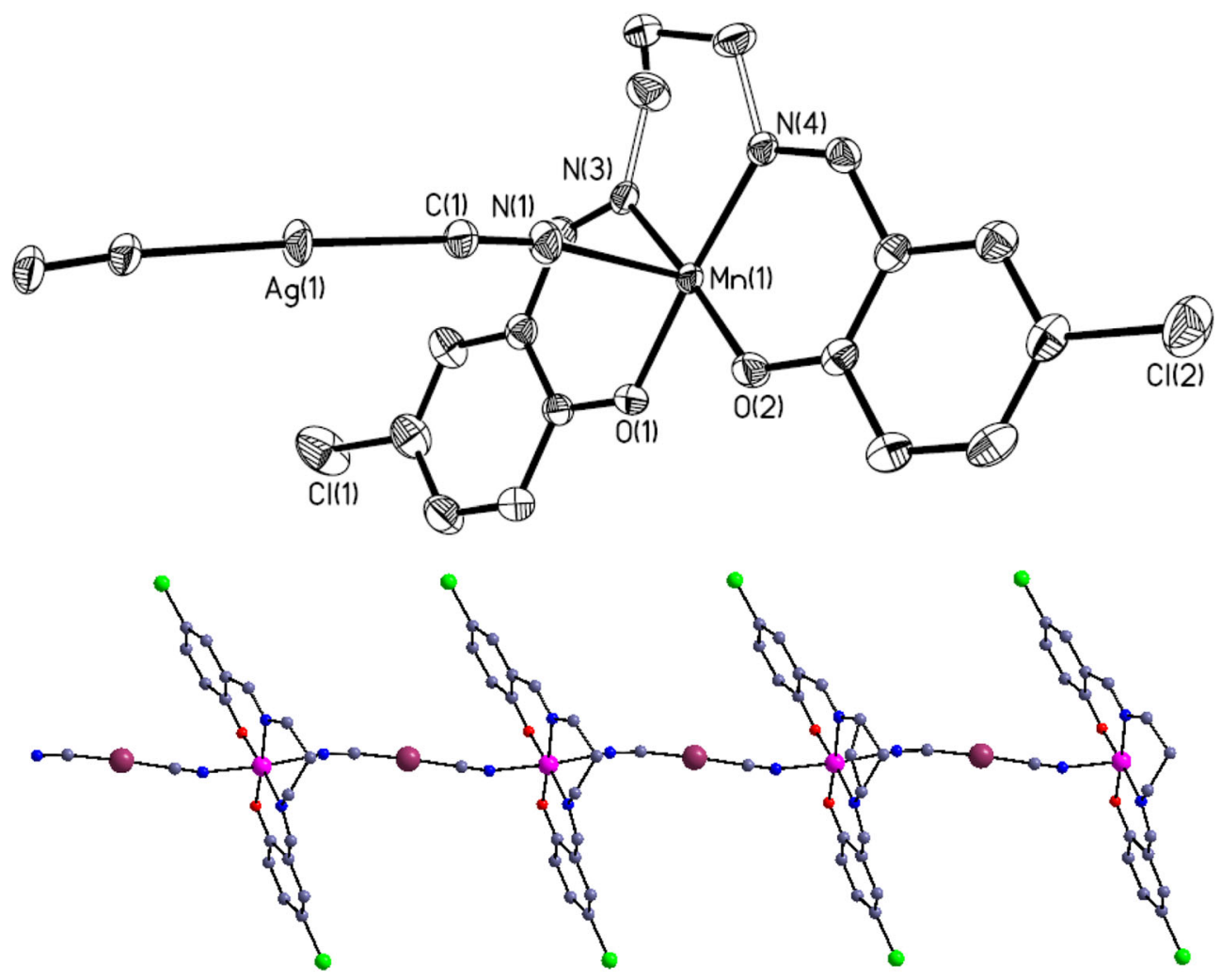

Figure 3. The asymmetric unit and the neutral one-dimensional chain structure of complex 3. Displacement ellipsoids are drawn at the $30 \%$ probability level. All the $\mathrm{H}$ atoms and the solvent molecules have been omitted for clarity. 


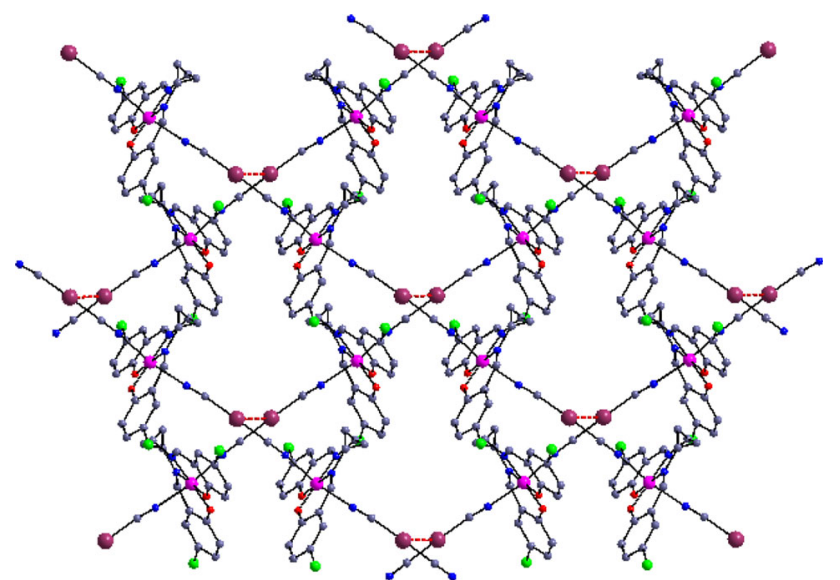

Figure 4. The two-dimensional double-layer supramolecular structure for complex 3 constructed by the weak Ag...Ag interactions. All the $\mathrm{H}$ atoms and the solvent molecules have been omitted for clarity.

the four $\mathrm{N}$ atoms of the macrocyclic ligand, thus forming a quasi-planar square geometry with unhindered axial sites.

$\mathrm{X}$-ray diffraction reveals the one-dimensional cationic infinite structure of complex 2, comprising of repeating [-NC-Ag-CN-Ni( $\left.\left.\mathrm{L}^{1}\right)-\right]$ unit with the positive charge balanced by the disordered $\left[\mathrm{Ag}(\mathrm{CN})_{2}\right]^{-}$anion. Each $\left[\mathrm{Ag}(\mathrm{CN})_{2}\right]^{-}$unit, acting as a bidentate ligand through its two trans cyanide groups, connects the $\mathrm{Ni}$ (II) ions of two independent macrocyclic nickel units. The Ni ion is coordinated by four $\mathrm{N}$ atoms of the macrocyclic ligand located in the equatorial plane and two $\mathrm{N}$ atoms of the bridge cyanide groups in trans position. The $\mathrm{Ni}-\mathrm{N}_{\text {macrocyclic }}$ bond lengths are 1.944(10), 2.079(14), 2.085(12) and 2.056(14) $\AA$, which are basically consistent with the corresponding distances in the mononuclear compound 1 (Table 2) but slightly shorter than the $\mathrm{Ni}-\mathrm{N}_{\text {cyanide }}$ bond lengths with the values 2.14(3) and 2.12(3) $\AA$, indicating that the coordination sphere of the $\mathrm{Ni}$ atom is a slightly distorted octahedron. The Ni-N $\equiv$ $\mathrm{C}$ bond angle is a little bent from the linear conformation with the value of $168.1(2)^{\circ}$. The intramolecular $\mathrm{Ni}^{\mathrm{II}}-\mathrm{Ni}^{\mathrm{II}}$ separation through bridging cyanide precursor is about $10.53 \AA$.

Some selected bond distances and bond angles for complexes $\mathbf{3}$ and $\mathbf{4}$ are collected in Table 3. The asymmetric unit, the neutral one-dimensional chain and the two-dimensional double-layer supramolecular structure for complex 3 are shown in Figures 3 and 4, respectively. For complex 4, its cationic trinuclear structure and the cell packing diagram are depicted in Figure 5.

Complexes 3 and 4, which contain eight and four independent units in the unit cell, crystallize in the same monoclinic cell setting $\mathrm{C} 2 / \mathrm{c}$ space group but
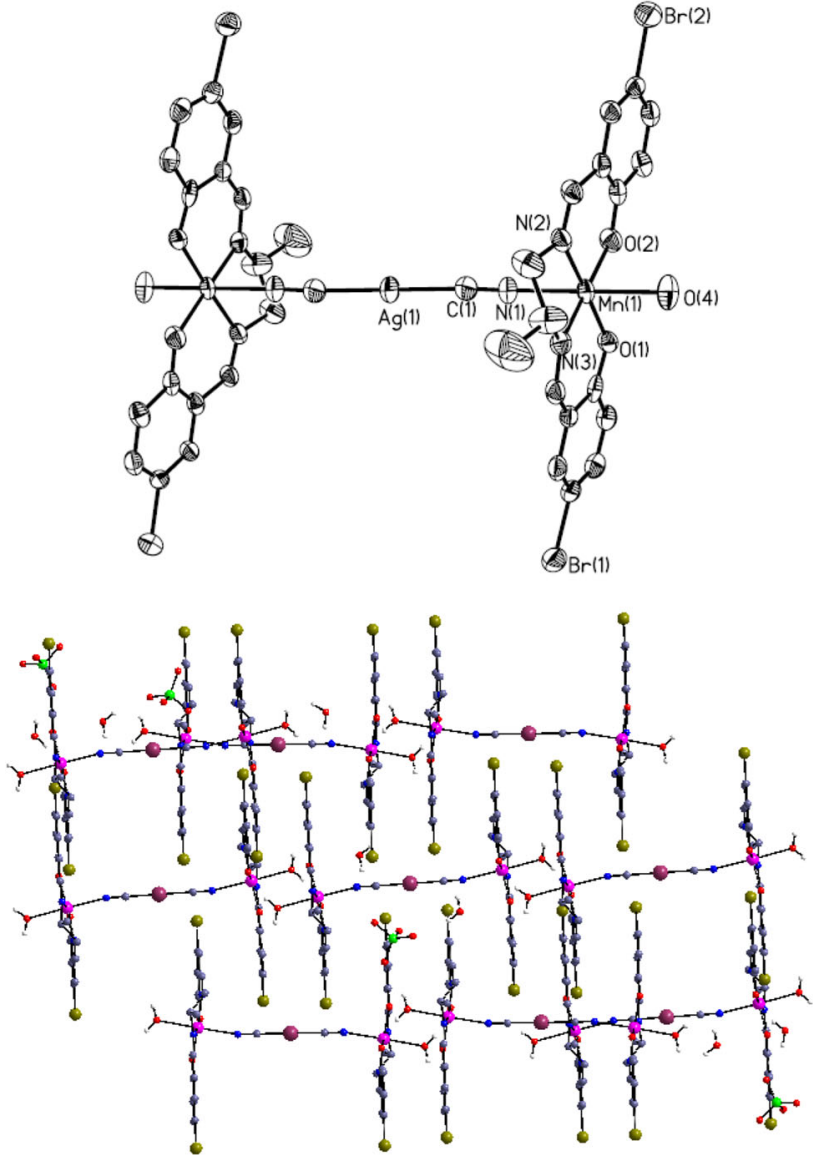

Figure 5. The cationic trinuclear structure and the cell packing diagram along $b$ axis for complex 4. Displacement ellipsoids are drawn at $30 \%$ probability level. All the non-solvent $\mathrm{H}$ atoms except those of the water molecules have been omitted for clarity.

with different structural types. Complex 3 possesses a neutral infinite linear chain structure consisting of alternate $\operatorname{Ag}(\mathrm{I})$ and $\mathrm{Mn}(\mathrm{III})$ ions. In the chains, each trans- $\left[\mathrm{Ag}(\mathrm{CN})_{2}\right]^{-}$connects two $\left[\mathrm{Mn}\left(\mathrm{L}^{2}\right)\right]^{+}$with two trans-cyanide groups, and in turn, each trans $-\left[\mathrm{Mn}\left(\mathrm{L}^{2}\right)\right]^{+}$ unit links two trans- $\left[\mathrm{Ag}(\mathrm{CN})_{2}\right]^{-}$building blocks, in which the $\left[\mathrm{Ag}(\mathrm{CN})_{2}\right]^{-}$and $\left[\mathrm{Mn}\left(\mathrm{L}^{2}\right)\right]^{+}$groups are disposed parallel to each other. It should be noted that the 1D chain structure of the complex $\mathbf{3}$ can be further extended into the supramolecular 3D network with the help of weak $\mathrm{Ag}$... Ag interactions between the different chains in vertical directions. Different from that of the complex $\mathbf{3}$, the structure of the complex $\mathbf{4}$ belongs to cyanide-bridged cationic sandwich-like type containing trinuclear $\mathrm{Mn}_{2} \mathrm{Ag}$ core, in which the cyanide precursor anion acting as bidentate ligand connects two Schiffbase manganese(III) units through its two trans cyanide groups, with positive charge balanced by the free $\mathrm{ClO}_{4}^{-}$ anion. 

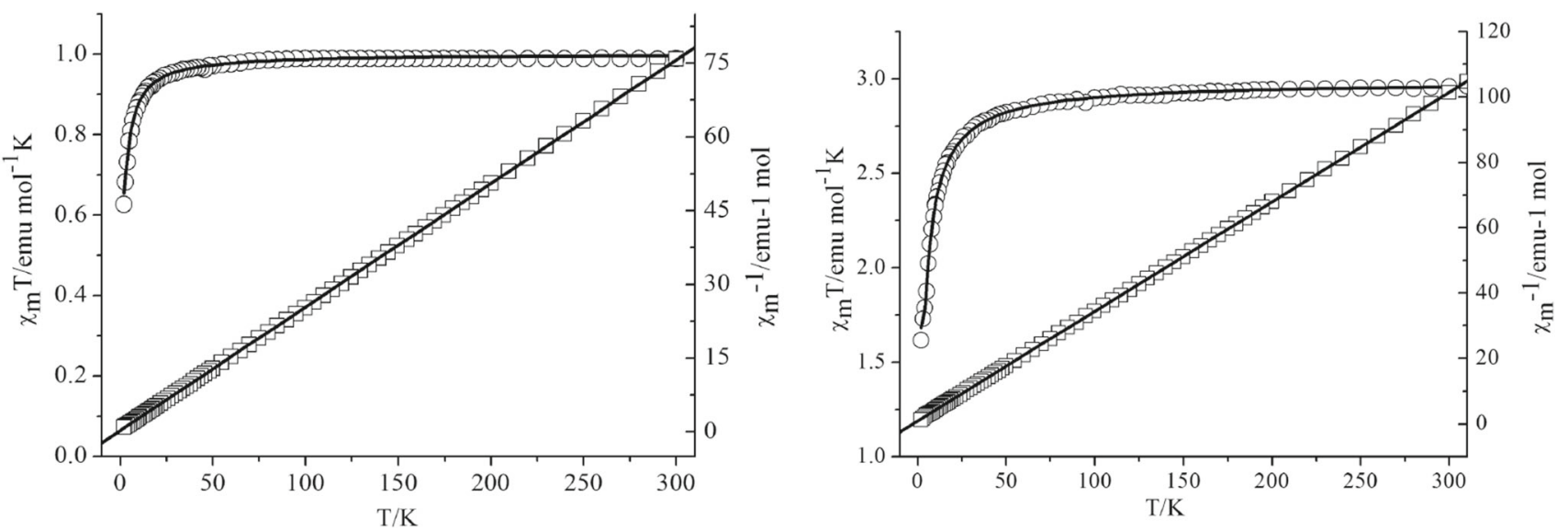

Figure 6. The $\chi_{\mathrm{m}} \mathrm{T}$ and $\chi_{\mathrm{m}}^{-1}$ vs $\mathrm{T}$ curves for complex 2 (left) and complex 4 (right). The solid lines represent to the best fit curves.

The $\mathrm{Mn}(\mathrm{III})$ ion in the complexes $\mathbf{3}$ and $\mathbf{4}$ is six-coordinated, forming a slightly distorted octahedral coordination geometry, in which the four equatorial positions are occupied by $\mathrm{N}_{2} \mathrm{O}_{2}$ unit coming from the Schiff-base ligand, two axial ones coordinated by two $\mathrm{N}$ atoms of cyanide groups in complex $\mathbf{3}$, and one cyanide $\mathrm{N}$ atom and one $\mathrm{O}$ atom of the coordinated water molecule in complex 4. As shown in Table 3, the $\mathrm{Mn}-\mathrm{N}_{\text {cyanide }}$ and $\mathrm{Mn}-\mathrm{O}_{\text {water }}$ bond lengths with the values 2.242(6), 2.260(6), 2.264(9) and 2.317(7) , respectively, are obviously longer than the average $\mathrm{Mn}$ $\mathrm{N}_{\text {Schiff-base }}$ and Mn- $\mathrm{O}_{\text {Schiff-base }}$ bond lengths within the range of 1.969(9)-2.054(6) and 1.861(7)-1.896(5) А, which give rise to an elongated octahedral geometry around the $\mathrm{Mn}(\mathrm{III})$, with the Jahn-Teller axis lying along the $z$ direction, i.e., the $\mathrm{N}_{\text {cyanide }}-\mathrm{Mn}-\mathrm{N}_{\text {cyanide }}$ axis. The $\mathrm{Mn}-\mathrm{N} \equiv \mathrm{C}$ bond angles in these two complexes are 168.0(6) and $163.6(11)^{\circ}$, respectively, indicating that these three atoms deviate slightly from a linear configuration. The intramolecular distances between the two $\mathrm{Mn}$ (III) ion bridged by the long diamagnetic $\left[\mathrm{Ag}(\mathrm{CN})_{2}\right]^{-}$are 10.766 in $\mathbf{3}$ and $10.750 \AA$ in $\mathbf{4}$, respectively.

\subsection{Magnetic properties of complexes 2-4}

As described above, the $\left[\mathrm{Ni}\left(\mathrm{L}^{1}\right)\right]^{2+}$ is a planar diamagnetic compound, while the six-coordinated paramagnetic $\mathrm{Ni}$ (II) ions in the complex are bridged by the cyanide precursor. For complexes $\mathbf{3}$ and 4, from the molecular magnetism of the view, both the complexes contain the diamagnetic cyanide building block-bridged $\mathrm{Mn}$ (III) ions. Therefore, investigation of the magnetic properties of the complexes, with complexes $\mathbf{2}$ and $\mathbf{4}$ as representatives, were carried out, and the temperature dependence of magnetic susceptibility for these two complexes were measured in the range of 2-300 $\mathrm{K}$ under the external magnetic field of 2000 Oe. These are shown in Figure 6. The room temperature values of $\chi_{m} \mathrm{~T}$ are 0.95 and $2.96 \mathrm{emu} \mathrm{K} \mathrm{mol}^{-1}$ for complexes 2 and $\mathbf{4}$, respectively, slightly lower than the spin only value 1.0 and $3.0 \mathrm{emu} \mathrm{K} \mathrm{mol}^{-1}$ for the isolated $\mathrm{Ni}(\mathrm{II})(\mathrm{S}=1)$ ion and the $\mathrm{Mn}(\mathrm{III})(\mathrm{S}=2)$ ion with $\mathrm{g}=2.0$. With the lowering of temperature, the $\chi_{m} \mathrm{~T}$ value remains almost constant until about $50 \mathrm{~K}$, and then decreases rapidly to the lowest value of 0.615 and $1.614 \mathrm{emu} \mathrm{K} \mathrm{mol}^{-1}$ at 2.0 $\mathrm{K}$. The magnetic susceptibility obeys Curie-Weiss law in the range of 20-300 K, and affords negative Weiss constant $\theta \theta=-2.91 \mathrm{~K}$ and Curie constant $C=1.16$ emu $\mathrm{K} \mathrm{mol}^{-1}$ for complex 2 , and $\theta \theta=-3.98 \mathrm{~K}$ and Curie constant $C=2.84 \mathrm{emu} \mathrm{K} \mathrm{mol}^{-1}$ for complex 4 . This primarily indicates that the antiferromagnetic coupling between the cyanide-bridged Ni(II) or Mn(III) ion in these two complexes.

The magnetic properties for complexes $\mathbf{2}$ and $\mathbf{4}$ have been simulated by using the dimeric model with the following Hamilton, in which the zero-split effect of the $\mathrm{Mn}(\mathrm{III})$ ion in complex 4 was considered due to its obviously elongated octahedral coordination sphere, typical of the Jahn-Teller effect. ${ }^{40}$

$$
\begin{aligned}
H= & -2 J S_{1} S_{2} \\
H= & -2 J S_{1} S_{2}+D_{1}\left[S_{1 z}^{2}-1 / 3 S_{1}\left(S_{1}+1\right)\right] \\
& +D_{2}\left[S_{1 z}^{2}-1 / 3 S_{2}\left(S_{2}+1\right)\right]
\end{aligned}
$$

The magnetic data between $2-300 \mathrm{~K}$ were fitted, resulting in the best fitting parameters which match the experimental data are $J=-0.51 \mathrm{~cm}^{-1}, g=2.01$ and $J=-0.78 \mathrm{~cm}^{-1}, D=-1.91 \mathrm{~cm}^{-1}, g=2.02$ for complexes 2 and $\mathbf{4}$, respectively. The small $J$ values can be attributed to the long distance between the paramagnetic metal ions separated by the long diamagnetic dicyanometallate. 


\section{Conclusions}

In summary, with a new macrocylic Nickel(II) compound, structurally confirmed for the first time, and two different Schiff-base Manganese(III) compounds as assembling segments and trans-dicyanometallate as a building block, three new heterobimetallic cyanidebridged complexes have been synthesized and structurally characterized as one-dimensional polymer or cationic trinuclear entity. For the 1D cyanide-bridged $\mathrm{Mn}(\mathrm{III})-\mathrm{Ag}(\mathrm{I})$ compound, the one-dimensional chain can be further extended into three-dimensional supramolecular structure depending on the weak Ag... Ag interactions between the adjacent chains in the vertical directions. Investigation of the magnetic properties of complexes 2-4 showed weak anti-ferromagnetic coupling between neighboring $\mathrm{Ni}(\mathrm{II})$ or $\mathrm{Mn}$ (III) ions.

\section{Acknowledgements}

This work was supported by the Natural Science Foundation of China (21671121).

\section{References}

1. Verdaguer M, Bleuzen A, Marvaud V, Vaissermann J, Seuleiman M, Desplanches C, Scuiller A, Train C, Garde R, Gelly G, Lomenech C, Rosenman I, Veillet P, Cartier dit Moulin C and Villain F 1999 Molecules to build solids: high TC molecule-based magnets by design and recent revival of cyano complexes chemistry Coord. Chem. Rev. 1921023

2. Cornia A, Mannini M, Sainctavit P and Sessoli R 2011 Chemical strategies and characterization tools for the organization of single molecule magnets on surfaces Chem. Soc. Rev. 403076

3. Lescouëzec R, Vaisserman J, Ruiz-Pérez C, Lloret F, Carrasco R, Julve M, Verdaguer M, Dromzee Y, Gatteschi D and Wernsdorfer W 2003 CyanideBridged Iron(III)-Cobalt(II) Double Zigzag Ferromagnetic Chains: Two New Molecular Magnetic Nanowires Angew. Chem. Int. Edit. 421483

4. Miyasaka H, Saitoh A and Abe S 2007 Magnetic assemblies based on Mn(III) salen analogues Coord. Chem. Rev. 2512622 and references therein

5. Dunbar K R and Heintz R A 2009 Cyanidec-Bridged Complexes of Transition Metals: A Molecular Magnetism Perspective Prog. Inorg. Chem. 57155

6. Wang S, Ding X H, Li Y H and Huang W 2012 Dicyanometalate chemistry: A type of versatile building block for the construction of cyanide-bridged molecular architectures Coord. Chem. Rev. 256439

7. Entley W R and Girolami G S 1995 High-Temperature Molecular Magnets Based on Cyanovanadate Building Blocks: Spontaneous Magnetization at 230 K Science 268397

8. Hatlevik $\varnothing$, Buschmann W E, Zhang J, Manson J L and Miller J S 1999 Enhancement of the Magnetic Ordering
Temperature and Air Stability of a Mixed Valent Vanadium Hexacyanochromate(III) Magnet to $99^{\circ} \mathrm{C}(372 \mathrm{~K})$ Adv. Mater. 11914

9. Bleuzen A, Lomenech C, Escax V, Villain F, Varret F, Cartier dit Moulin C and Verdaguer M 2000 Photoinduced Ferrimagnetic Systems in Prussian Blue Analogues $\mathrm{C}_{\mathrm{x}}^{\mathrm{I}} \mathrm{Co}_{4}\left[\mathrm{Fe}(\mathrm{CN})_{6}\right]_{\mathrm{y}}\left(\mathrm{C}^{\mathrm{I}}=\right.$ Alkali Cation $) .1$. Conditions to Observe the Phenomenon J. Am. Chem. Soc. 1226648

10. Ababei R, Pichon C, Roubeau O, Li Y G, Bréfuel N, Buisson L, Guionneau $\mathrm{P}$, Mathonière $\mathrm{C}$ and Clérac $\mathrm{R}$ 2013 Rational Design of a Photomagnetic Chain: Bridging Single-Molecule Magnets with a Spin-Crossover Complex J. Am. Chem. Soc. 13514840

11. Bleuzen A, Marvaud V, Mathonière C, Sieklucka B and Verdaguer M 2009 Photomagnetism in Clusters and Extended Molecule-Based Magnets Inorg. Chem. 48 3453

12. Jeon I R, Calancea S, Panja A.; Piñero Cruz D M, Koumousi ES, Dechambenoit P, Coulon C, Wattiaux A, Rosa P, Mathonière C and Clérac R 2013 Spin crossover or intra-molecular electron transfer in a cyanido-bridged Fe/Co dinuclear dumbbell: a matter of state Chem. Sci. 4 2463

13. Volatron F, Catala L, Rivière E, Gloter A, Stephan O and Mallah T 2008 Spin-Crossover Coordination Nanoparticles Inorg. Chem. 476584

14. Bartual-Murgui C, Salmon L, Akou A, Ortega-Villar N A, Shepherd H J, Muñoz M C, Molnár G, Real J A and Bousseksou A 2012 Synergetic Effect of Host-Guest Chemistry and Spin Crossover in 3D Hofmann-like Metal-Organic Frameworks [Fe(bpac) $\left.\mathrm{M}(\mathrm{CN})_{4}\right](\mathrm{M}=\mathrm{Pt}$, Pd, Ni) Chem. Eur. J. 18507

15. Trzop E, Zhang D P, Piñiro-Lopez L, Valverde-Muñoz F J, Muñoz M C, Palatinus L, Guerin L, Cailleau H, Real J A and Collet E 2016 First Step Towards a Devil's Staircase in Spin-Crossover Materials Angew. Chem. Int. Edit. 558675

16. Zhang D P, Trzop E, Valverde-Muñoz F J, PiñeiroLópez L, Muñoz M C, Collet E and Real J A 2017 Competing Phases Involving Spin-State and Ligand Structural Orderings in a Multistable Two-Dimensional Spin Crossover Coordination Polymer Cryst. Growth Des. 172736

17. Kaneko W, Kitagawa S and Ohba M 2007 Chiral Cyanide-Bridged $\mathrm{Mn}^{\mathrm{II}} \mathrm{Mn}^{\mathrm{III}}$ Ferrimagnets, $\left[\mathrm{Mn}^{\mathrm{II}}(\mathrm{HL})\left(\mathrm{H}_{2} \mathrm{O}\right)\right]\left[\mathrm{Mn}^{\mathrm{III}}(\mathrm{CN})_{6}\right] \cdot 2 \mathrm{H}_{2} \mathrm{O} \quad(\mathrm{L}=\mathrm{S}$ - or R-1,2-diaminopropane): Syntheses, Structures, and Magnetic Behaviors J. Am. Chem. Soc. 129248

18. Zhu Y Y, Guo X, Cui C, Wang B W, Wang Z M and Gao S 2011 An enantiopure $\mathrm{Fe}_{4}^{\mathrm{III}}$ single-molecule magnet Chem. Commun. 478049

19. Ru J, Gao F, Wu T, Yao M X, Li Y Z and Zuo J L 2014 Enantiopure heterobimetallic single-chain magnets from the chiral $\mathrm{Ru}^{\mathrm{III}}$ building block Dalton Trans. 43933

20. Zhang D P, Zhuo S P, Zhang H Y, Wang P and Jiang J Z 2015 Synthesis, crystal structures and magnetic properties of mer-cyanideiron(III)-based 1D heterobimetallic cyanide-bridged chiral coordination polymers Dalton Trans. 444655

21. Zhang D P, Wang P, Chen K X and Chen X 2014 Cyanideand phenoxo-bridged heterobimetallic Fe(III)-Mn(III) 
complexes: Synthesis, crystal structures and magnetic properties J. Chem. Sci. 1261665

22. Freedman D E, Jenkins D M, Iavarone A T and Long J R 2008 A Redox-Switchable Single-Molecule Magnet Incorporating $\left[\operatorname{Re}(\mathrm{CN})_{7}\right]^{3-}$ J. Am. Chem. Soc. 1302884

23. Goodwin A L, Kennedy B J and Kepert C 2009 Thermal Expansion Matching via Framework Flexibility in Zinc Dicyanometallates J. Am. Chem. Soc. 1316334

24. Mai S L, Ren S, Ma Y and Liao D Z 2009 Sheet-like of $\mathrm{Mo}^{\mathrm{V}}-\mathrm{Sm}^{\mathrm{III}}$ assembly containing $\left[\mathrm{Mo}^{\mathrm{V}}(\mathrm{CN})_{8}\right]^{3-}$ and Sm3+ ions as building blocks J. Chem. Sci. 121421

25. Toma L M, Lescouëzec R, Pasan J, Ruiz-Perez C, Vaissermann J, Cano J, Carrasco R, Wernsdorfer W, Lloret $\mathrm{F}$ and Julve M $2006\left[\mathrm{Fe}(\text { bpym })(\mathrm{CN})_{4}\right]^{-}$: A New Building Block for Designing Single-Chain Magnets J. Am. Chem. Soc. 1284842

26. Zhang D P, Zhang L F, Chen Y T, Wang H L, Ni Z H, Wernsdorfer W and Jiang J Z 2010 Heterobimetallic porphyrin-based single-chain magnet constructed from manganese(III)-porphyrin and transdicyanobis(acetylacetonato) ruthenate(III) containing co-crystallized bulk anions and cations Chem. Commun. 463550

27. Chen X, Wu S Q, Cui A L and Kou H Z 2014 A cyanobridged single-chain magnet featuring alternate highand low-spin manganese(III) porphyrins Chem. Commun. 502120

28. Venkatakrishnan T S, Sahoo S, Bréfuel N, Duhayon C, Paulsen C, Barra A L, Ramasesha S and Sutter J P 2010 Tuning Supramolecular Rigidity of Peptide Fibers through Molecular Structure J. Am. Chem. Soc. 1326047

29. Paraschiv C, Andruh M, Journaux Y, Zâk Z, Kyritsakasd $\mathrm{N}$ and Ricard L 2006 Trinuclear magnetic clusters based on cyanide metal complexes: synthesis, crystal structures, and magnetic properties of four new $\left[\mathrm{Mn}_{2}^{\mathrm{II}} \mathrm{M}^{\mathrm{III}}\right]$ complexes ( $\mathrm{M}=\mathrm{Cr}, \mathrm{Fe}, \mathrm{Co})$ J. Mater. Chem. 162660

30. Qian K, Huang X C, Zhou C, You X Z, Wang X Y and Dunbar K R 2013 A Single-Molecule Magnet Based on Heptacyanomolybdate with the Highest Energy Barrier for a Cyanide Compound J. Am. Chem. Soc. 13513302

31. Zhang D P, Si W J, Wang P, Chen X and Jiang J Z 2014 $1 D$ to 3D Heterobimetallic Complexes Tuned by Cyanide Precursors: Synthesis, Crystal Structures, and Magnetic Properties Inorg. Chem. 533494
32. Zhang D P, Wang H L, Chen $\mathrm{Y}$ T, Ni Z H, Tian L J and Jiang J Z 2009 Rational Design and Assembly of a New Series of Cyanide-Bridged Fe ${ }^{\mathrm{III}}-\mathrm{Mn}^{\mathrm{II}}$ OneDimensional Single Chain Complexes: Synthesis, Crystal Structures, and Magnetic Properties Inorg. Chem. 48 5488

33. Zhang H Y, Xue C C, Shi J W, Liu H, Dong Y H, Zhao Z D, Zhang D P and Jiang J Z 2016 Coordination Field Tuned Cyanide-Bridged Polynuclear and One-Dimensional Heterobimetallic Complexes: Synthesis, Crystal Structures, and Magnetic Properties Cryst. Growth Des. 165753

34. Mudsainiyan R K, Jassal A K, Arora M and Chawla S K 2015 Synthesis, crystal structure determination of two-dimensional supramolecular co-ordination polymer of silver(I) with 1,2-Bis(phenylthio)ethane and its Hirshfeld surface analysis J. Chem. Sci. 127 849

35. Li Y, Zhang W L, Du H J, Wang C H, Lu Y B and Niu Y Y 2015 Three silver (I) supramolecular compounds constructed from pyridinium or methylimidazolium polycations: Synthesis, crystal structure and properties J. Chem. Sci. 1271513

36. Bhattacharya S and Saha B K 2016 Conformation driven complexation of two analogous benzimidazole based tripodal ligands with $\mathrm{Ag}(\mathrm{I})$ resulting in a trigonal prism and a coordination polymer J. Chem. Sci. $\mathbf{1 2 8}$ 207

37. Karn J L and Busch D H 1969 Nickel(II) complexes of the new macrocyclic ligands meso- and (+-)-2,12dimethyl-3,7,11,17-tetraazabicyclo [11.3.1] heptadeca1(17),13,15-triene Inorg. Chem. 81149

38. Ni Z H, Zhang L F, Cui A L, Ni W W, Zhao C C and Kou H Z 2007 Cyanido-Bridged Dimetallic Complexes Derived from Manganese(III) Schiff Bases and Pentacyanidonitrosylchromate(I): Synthesis, Crystal Structure and Magnetic Properties Eur. J. Inorg. Chem. 91240

39. Sheldrick, G. M. SHELX-97, Universität Göttingen, Germany, 1997

40. Kennedy B J and Murray K S 1985 Magnetic properties and zero-field splitting in high-spin manganese(III) complexes. 1. Mononuclear and polynuclear Schiff-base chelates Inorg. Chem. 241552 